Article

\title{
Development of Damage Prediction Formula for Natural Disasters Considering Economic Indicators
}

\author{
Young Seok Song $(\mathbb{D}$ and Moo Jong Park *(i) \\ Department of Construction Engineering, Hanseo University, Seosan-si 31962, Korea; kind711@hanmail.net \\ * Correspondence: mjpark@hanseo.ac.kr; Tel.: +82-41-660-1051
}

Received: 1 January 2019; Accepted: 2 February 2019; Published: 7 February 2019

\begin{abstract}
Damage caused by natural disasters produces the difference of damage size not only according to damage volume or size, but a national economic level. In addition, budgets and aids should be constantly acquired for disaster management since natural disasters sporadically or irregularly occur. This study proposed disaster management methods by countries considering natural disaster damage documents and economic indicators from 1900 to 2017 among 187 countries in the world. It developed a damage prediction formula considering damage documents of previous natural disasters, economic indicators by countries, and basic indicators as disaster management methods by countries. Independent variables of the damage prediction formula include GDP, population, and area. It applied multiple regression analysis and calculated average human losses due to death, human losses affected, and damage costs by countries. Regarding the adjusted $\mathrm{R}^{2}$ of the natural disaster damage prediction formula, the human losses from deaths mean was 0.893 , the human losses affected mean was 0.915 , and the damage costs mean was 0.946 , which had higher explanatory powers. Therefore, results from this study are considered to calculate quantitative damage sizes considering uncertain damage sizes of natural disasters, economic indicators by countries, and are used as indicators for disaster management.
\end{abstract}

Keywords: natural disaster; damage prediction; economic indicators; human losses; damage costs

\section{Introduction}

Natural disasters sweeping the world are unpredictable in terms of damage size and damage scope. Studies are conducted to predict natural disasters and prepare for them in many different countries. Natural disasters are events that repeatedly cause damage and economic loss in various fields. Natural disasters have long been an area of great interest in the international community. Despite various studies and disaster reduction, the frequency and size of disasters continues to increase. Although the effects of natural disasters on humans are extensive, economic development for human convenience makes the damage worse [1].

Abnormal climates frequently occur due to effects from the recent climate change and national development projects, which increases the possibility of occurring disasters and massive damages [2-5]. For this reason, a variety of research on disaster management is conducted in many countries to improve the ability to predict and prepare for natural disasters. In addition, plenty of research has been done on natural disasters and economic impacts, but natural disasters and economic impacts are estimated to have positive or negative impacts [6]. Various prior studies on natural disasters and economic indicators are presented in detail in Chapter 2.

This study aims to develop a natural disaster damage prediction formula considering national disaster damage data, economic indicators, and basic indicators by countries in the world. Human losses from deaths, human losses affected, and damage costs were selected as natural disaster damage data. GDP, population, and area were selected as economic indicators and basic indicators by countries. 
For natural disaster damage data, it calculated annual average costs by countries and the 2017 standard aimed to be applied for economic indicators and basic indicators by countries. The appropriateness of medium variables will analyze the significance through correlation analysis and a damage prediction formula will be proposed through multiple regression analysis.

\section{Literature Review}

The damage size of natural disasters is produced by considering various effects of not just types and sizes of disasters, but national social and economic factors. Recent studies related with disasters are performed to estimate damage sizes by using various medium variables such as previous damage data, economic indicators by countries, and basic indicators on disasters including heavy rain, earthquake, and hurricane [7-13].

We have developed a formula for economic development and natural disasters in 151 countries for about 40 years against human losses due to deaths and damage/GDP due to natural disasters. The parameters include GDP, total schooling years, size of government, openness, and M3/GDP. The analytical conditions developed a formula for human losses deaths and damage/GDP for 151 countries, OECD countries, and developing countries. The correlation of R2 was 0.09 to 0.35 . The correlation coefficient between GDP and various parameters of the formula was less than $\pm 1 \%$ to $2 \%$ [14]. In addition, the economic parameters are similar, but the relationship between the economic situation and economic impacts in 1985, 1995, and 2005 was analyzed for 73 countries. Death, human losses affected, and damage/GDP from natural disasters were calculated. R2 is 0.02 to 0.40 but there is a significant relationship between economic effects and natural disaster damage [15]. A formula was proposed to calculate the damage caused by natural disasters and economic development in each country. However, there was not much difference in the application of the various economic parameters in each country and the result of applying only GDP. In addition, high correlation was not analyzed in national economic development by year. Thus, it is believed that the development of the damage prediction formula for natural disasters could be developed in a simpler way if only GDP is taken into account rather than the application of various parameters.

Natural disaster damage tended to decrease as educational level and economic size increased. In addition, population and economic growth were presented, as significant factors of rising damage on natural disasters. Non-linear U-shaped correlation was analyzed on national development and disaster damage [16-19]. The government proposed that information and education should be conducted not only for the physical equipment to reduce natural disasters but also for the collective action of citizens. We analyzed the degree of exposure due to various natural disasters and the loss relation to the economic development stage by country. Countries with low or moderate risk of natural disasters have reduced economic losses and wealth, while higher countries have an increasing impact [20,21]. The study on natural disaster and national economic indicators proposed the association between natural disaster damage and economic indicators, but did not calculate quantitative damage size for managing disasters in countries. In addition, the analysis of the natural disaster risks and economic indicators, according to the level of economic development in each country, has not been developed.

The occurrence of natural disasters affects national economic growth, population, and GDP for short and long periods. Disaster size and national competitiveness were highly correlated with damage restoration power [22-26]. Although agriculture is badly affected by flood in the middle part of the United States, employment was less influenced. Even if hurricanes and storms swept big cities in the Texas Gulf Coast, the population and GDP increased. It was analyzed that natural disasters facilitated the economy for a short period in Vietnam [27-30]. We have developed multiple regression formulas for the mortality rates of human as well as architectural, social, natural, and capital resources in the coastal areas due to hurricanes. The analysis found that the death rate was significantly affected by the hurricane frequency and the negative effects of the ecological economy and GDP. However, in developing countries in Central America and the Caribbean, hurricanes have fallen by $0.84 \%$ as along with life, monetary damage, and macroeconomic growth by country [31]. Although studies on the long 
and short-term effects on national population, economy, and development according to damage size of national disasters were conducted, there is little research on predicting natural disaster damage and proper disaster management response and preparation methods. Although the proposed reduction of natural disasters is caused by economic development by country, it is not only a result of hurricanes but also a result of various natural disasters.

We developed an analytical formula for predicting the damage to natural disasters, according to the level of economic development. Economic development reduces human damage and losses, but causes higher losses in higher-income countries [32]. However, in large-scale natural disasters, there is no mitigation effect due to economic growth in each country [6]. Without national economic development, it was analyzed that the death toll in natural disasters increased by $20 \%$. Therefore, it was proposed that international relief for developing countries should be promoted [33]. Regression analysis has been performed to estimate the damage from typhoons, heavy rain, hurricanes, and earthquakes by considering effects such as society, economy, and climate arisen from natural disasters. A damage prediction function was proposed by using regression analysis and the constant number law through medium variables including hurricane atmospheric pressure, wind speed, and size [8,34-38]. In addition, it analyzed the correlation through a linear relationship on the climate variable and the economic variable on various natural disasters and estimated a damage costs formula by conducting regression analysis [39-42]. The impact of natural disasters on economic development depends on the state of development of the country. We intend to develop a prediction formula for natural disasters that can take into account both economic indicators and basic indicators by 151 countries. Although the damage formula and the prediction function of various types of disasters were proposed, no research on considering a comprehensive natural disaster and a damage prediction formula to be applied in various countries has been carried out.

\section{Methods}

\subsection{Multiple Regression Analysis}

Regression analysis can be classified into simple regression analysis and multiple regression analysis, according to the distribution of variables. As shown in Formula (1), simple regression analysis means that a single dependent variable and a single independent variable assume a straight-line relationship of the first function regarding the relationship between both variables.

$$
Y=\beta_{0}+\beta_{1} X
$$

$X$ in this case, refers to an independent variable. $Y$ refers to a dependent variable and $\beta$ means a regression coefficient.

Multiple regression analysis is a method for estimating and predicting characteristics or the trend of population elicited by analyzing collected data. The main purpose is to estimate a value of the dependent variable when designating the value of the independent variable. Multiple regression analysis shows the straight-line relationship of the first function between more than two independent variables and a dependent variable, as shown in Formula (2).

$$
Y=\beta_{0}+\beta_{1} X_{1}+\beta_{2} X_{2}+\cdots++\beta_{i} X_{i}+\varepsilon
$$

$\mathrm{X}$ herein, refers to the independent variable and $\mathrm{Y}$ is the dependent variable. $\varepsilon$ is the constant number and $\beta_{0}, \beta_{1}, \beta_{2}, \ldots, \beta_{i}$ are regression coefficients.

It is important to review the validity of estimated multiple regression analysis and representation and accuracy on the given data. $R^{2}$, which is a coefficient of determination and VIF, and is a variance inflation factor, are applied as a method to specify the degree of multiple regression analysis among various specification methods. The coefficient of determination is SST (Total Sum of Squares) and SSE 
ratio, which is the sum of SSE (Explained Sum of Squares) and SSR (Residual Sum of Squares) and it is calculated by applying equations such as Formula (3) to Formula (6).

$$
\begin{gathered}
R^{2}=1-\frac{S S R}{S S T} \\
\mathrm{SST}=\sum_{i=1}^{n}\left(Y_{i}-\bar{Y}\right)^{2} \\
\mathrm{SSE}=\sum_{i=1}^{n}\left(\hat{Y}_{i}-\bar{Y}\right)^{2} \\
\mathrm{SSR}=\sum_{i=1}^{n} \hat{u}_{i}{ }^{2}
\end{gathered}
$$

$Y_{i}$ herein refers to the $i_{\text {th }}$ dependent variable and $\bar{Y}$ is the average of $Y_{i} \cdot u_{i}$ means the error of regression analysis.

The coefficient of determination $\left(R^{2}\right)$ is a parameter representing the correlation of independent variables with size regarding the total variation of the dependent variable and has the scope of $0 \leq R^{2} \leq 1$. However, a coefficient of determination $\left(R^{2}\right)$ increases as the number of independent variables rise in multiple regression analysis. A revised coefficient of determination of Formula (7) should be applied in the multiple regression analysis in order to improve weak points of this coefficient of determination. In addition, it is necessary to select only the most influential variable among many independent variables and include it in the regression model, or gradually eliminate the least influential variable to dependent variables to simplify the regression formula.

$$
R_{a d j}^{2}=1-\frac{S S E /(n-k-1)}{S S T /(n-1)}
$$

$n$ in this formula refers to sample size and $\mathrm{k}$ refers to an independent variable.

The Variance Inflation Factor calculates the degree of increasing the divergence of the estimated regression coefficient if an independent variable shows the correlation, as shown in Formula (8). Multicollinearity means that some independent variables of the model are correlated with other independent variables. The bigger multicollinearity means that a single independent variable depends on another independent variable, which violates the assumption of the independent variable. Since it enlarges the divergence of the regression coefficient, destabilizes the model, and makes it unpredictable, it causes a problem. If the divergence expansion coefficient is 1 , it means that there is no multicollinearity. If the divergence expansion coefficient is generally over 10 , it can be said that there is a problem in collinearity.

$$
V I F_{i}=\frac{1}{1-R_{i}^{2}}
$$

$R^{2}$ herein refers to a coefficient of determination.

\subsection{Correlation Analysis}

Correlation analysis is an analysis of measuring the correlation and direction on the linear relationship between two variables in probability theory and statistics. Both variables can show an independent relationship or are correlated. Correlation means the intensity of the relationship between two variables.

Pearson rank-order correlation coefficient, Kendall rank-order correlation coefficient, and Spearman rank-order correlation coefficient analysis methods are typically used in statistics. The correlation coefficient used for identifying the level of correlation does not describe the correlation, but merely shows the relevant degree between two variables. The correlation coefficient is analyzed 
between -1 and +1 . As the correlation coefficient nears \pm 1 , correlation between two variables nears perfect. As it nears 0 , there is no correlation between them. The + sign shows a positive correlation and the while-sign shows a negative correlation, according to the direction of correlation.

The pearson linear correlation coefficient is a statistical method measuring the degree of correlation among linearly related variables. It measures how linearity between two variables is high. High linearity with a straight line in the relationship of variables means a high correlation. Formula (9) shows the equation analyzing the Pearson linear correlation coefficient.

$$
\mathrm{r}=\frac{\sum_{i=1}^{M}\left(X_{i}-\bar{X}\right)\left(Y_{i}-\bar{Y}\right)}{\sqrt{\sum_{i=1}^{M}\left(X_{i}-\bar{x}\right)^{2}\left(Y_{i}-\bar{Y}\right)^{2}}}
$$

$\mathrm{r}=$ Pearson $\mathrm{r}$ correlation coefficient and $X_{i}, Y_{i}$ are the $\mathrm{i}_{\mathrm{th}}$ sample values of $\mathrm{X}$ and $\mathrm{Y}$ variables. $\bar{X}, \bar{Y}$, and mean values of $X$ and $Y$ variables and $M$ refers to the number of the sample.

The Kendall rank-order correlation coefficient is a statistical method of measuring the non-parametric correlation that measures the dependency between two variables. It calculates the size of the correlation rank-order coefficient between two variables by using data converted with data standards or ranking standards. Formula (10) shows the equation analyzing the Kendall rank-order correlation coefficient.

$$
\tau=\frac{N_{c}-N_{d}}{\frac{1}{2} N(N-1)}
$$

$\tau$ in this case, is the Kendall rank-order correlation coefficient. $N_{c}$ and $N_{d}$ are the number of concordant pairs and discordant pairs, respectively. $\mathrm{N}$ means the size of the variable.

Spearman rank-order correlation coefficient is a statistical method of measuring the non-parametric correlation that measures the dependency between two variables. It does not assume the distribution of data, measures variables with ranking or the size rank-order standard, and calculate the size of rank-order correlation coefficients between two variables. Formula (11) exhibits the equation analyzing the Spearman rank-order correlation coefficient.

$$
r_{s}=1-\frac{6 \sum d_{i}^{2}}{N\left(N^{2}-1\right)}
$$

$r_{s}$ in this formula means Spearman rank-order correlation coefficient and $d_{i}$ is the difference of $\mathrm{i}_{\text {th }}$ values from arranging values of two variables in the order of size. $N$ is the size of the variable.

\section{Materials}

\subsection{Study Area}

This study aims to develop a damage prediction formula by using economy indicators by countries, basic indicators, and damage status of natural disasters. Medium variables for developing a damage prediction formula on natural disasters include GDP (Gross Domestic Product), population, areas, and damage status of natural disasters. Medium variables by countries are provided by many different institutions. Analysis can be conducted after investing all documents on medium variables to develop a damage prediction formula.

With regard to medium variables by countries for developing a damage prediction formula of natural disasters, IMF (International Monetary Fund) provides GDP data from 194 countries, UN (United Nations) provides population data from 235 countries, CIA (Central Intelligence Agency) provides area data from 258 countries, and CRED (Center for Research on the Epidemiology of Disasters) damage the status of natural disaster data from 187 countries.

The world is divided into nine continents consisting of more than 230 countries. Countries where natural disasters hit in eight continents except for Antarctica were selected as target regions. Therefore, this study selected 187 countries where all data on medium variables can be applied among target 
regions for developing a natural damage prediction formula, as shown in Figure 1. Countries selected as target regions are presented in Table A1 (Appendix A).

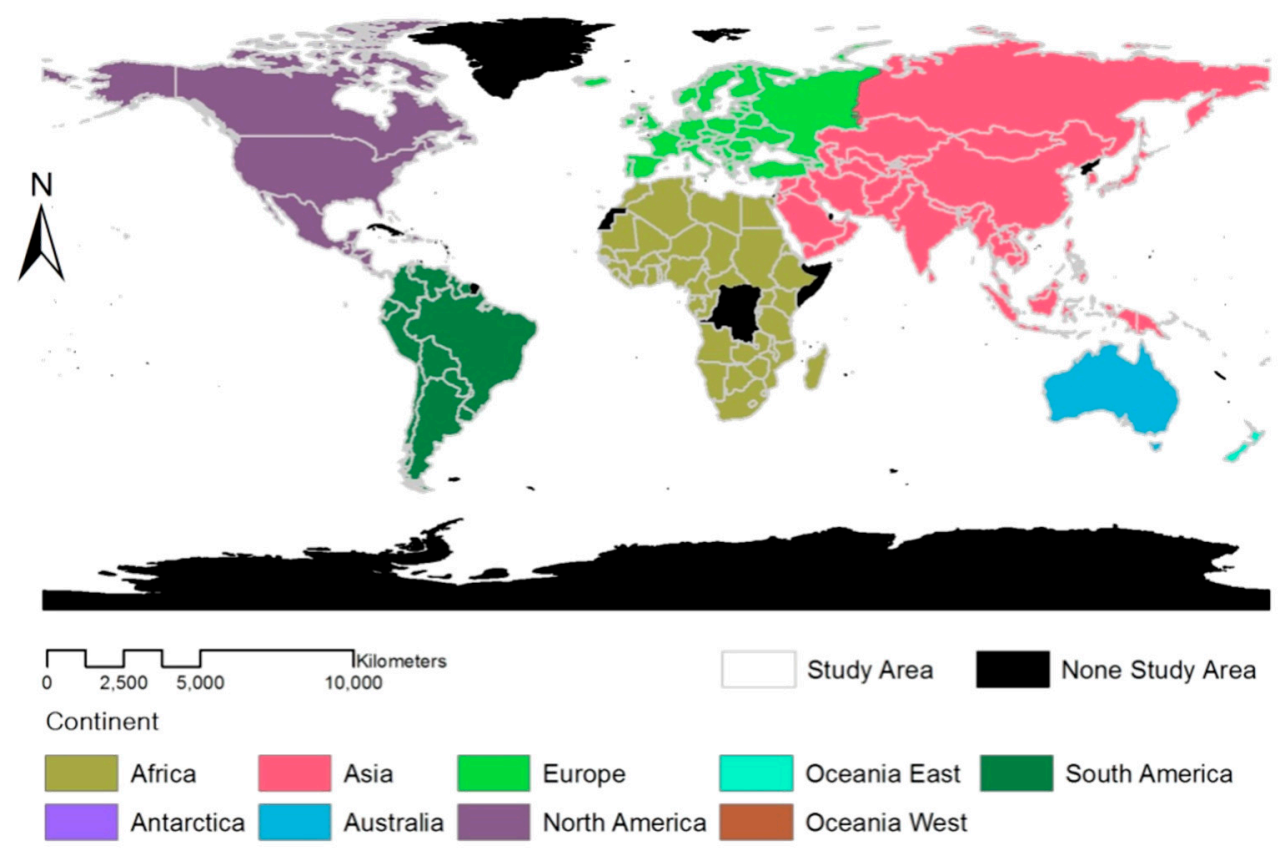

Figure 1. Study area.

\subsection{Damage Status of Natural Disasters}

CRED resolves health and disputes arisen from disasters, improves preparation and response to disasters, and provides data concerning disaster damage data arisen from national disasters. The CRED collects data associated with disasters through EM-DAT (the Emergency Events Database). As a source of data, data is collected from various institutions such as UN organizations, non-governmental organizations, insurance companies, research institutes, and media outlets. EM-DAT disaster data construction standards include human losses deaths with more than 10 people, human losses affected with more than 100 people, declaring a state of national emergency, and disasters requiring international aids. Human losses affected herein mean the occurrence of disasters, which encompass food, water, shelter, medical assistance, and injured people.

This study aims to analyze damage status by countries from 1900 to 2018 among natural disasters of disaster damage data provided by CRED through EM-DAT. The damage status was investigated by classifying natural disasters into 11 disaster types such as Biological, Climatological, Geophysical, Hydrological, and Meteorological in EM-DAT. The natural disaster damage status was investigated by being classified into human losses from deaths, human losses affected, and damage costs.

The number of natural disasters in the world from 1900 to 2017 was about 13,953. Human losses deaths in the world were about $28,669,875$. Human losses affected were $7,845,130,546$ and damage costs amount to $\$ 3,199,845,668$ thousand USD from 1900 to 2017, as shown in Table 1. The damage status of disaster types showed that human losses due to deaths in epidemics, earthquake, and flood account for nearly $85 \%$ of entire damages. Human losses affected in drought, flood, and typhoon account for nearly $96 \%$ of entire damages. Damage costs in drought, flood, and typhoon account for nearly $90 \%$ of entire damages. Tremendous damages were derived from earthquake, flood, and typhoon in the world when natural disasters hit. 
Table 1. Damage status of natural disaster types in the world (1900-2017).

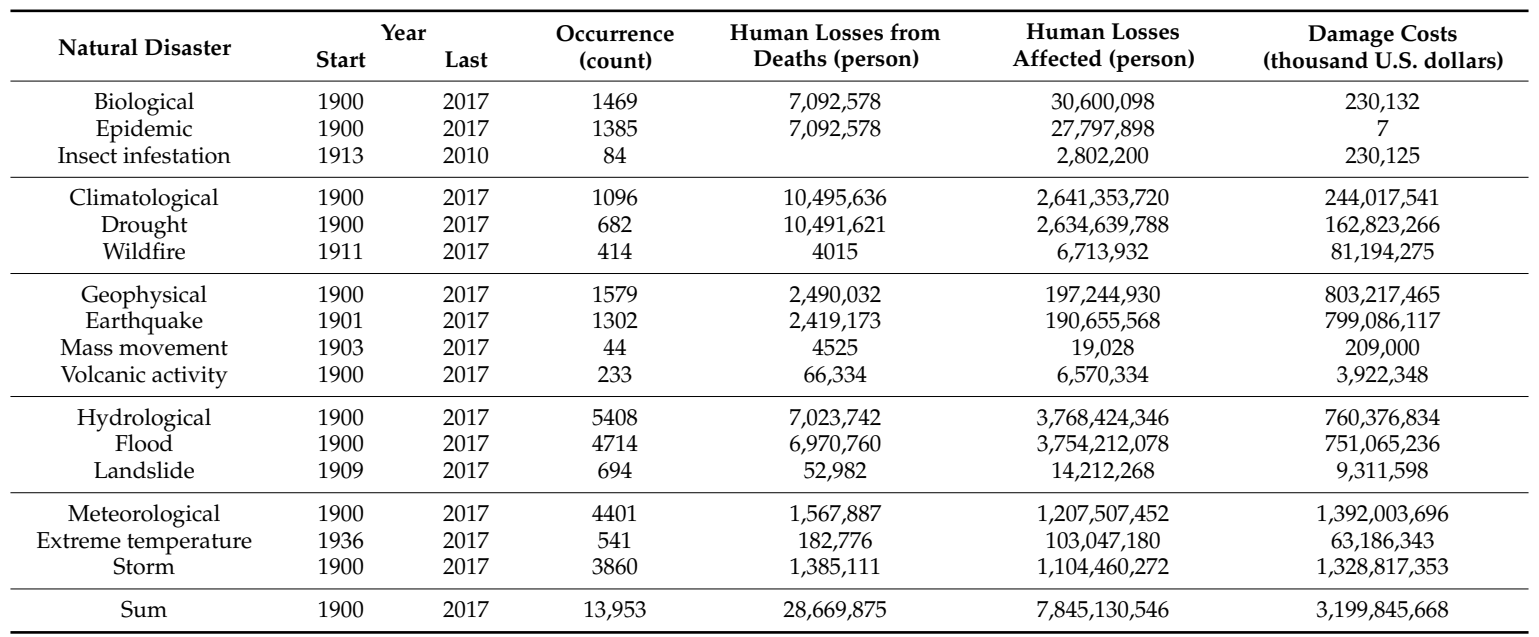

This study aims to analyze the damage status by countries from 1900 to 2017 among natural disasters of disaster damage data provided by CRED through EM-DAT. However, it is difficult to set identical standards on all countries as natural disaster damage data by countries, which vary in disaster occurrence time, disaster size, and data built-up time.

Therefore, this study intends to calculate annual averages on the damage status of natural disaster by countries including human losses due to deaths, human losses affected, and damage costs for developing a natural disaster damage prediction formula. A method of calculating annual averages on damage status of natural disaster by countries is multiplying the total numbers of occurring natural disasters on natural disaster damage with a percentage of observation years, as shown in Formula (12).

$$
N D A A_{D C S \cdot H L D \cdot H L A}=\frac{N D D_{D C S \cdot H L D \cdot H L A}}{\sum_{i=\text { year }} N D O C_{D C S \cdot H L D \cdot H L A} / D U R\left(Y_{L O}-Y_{S O}+1\right)_{D C S \cdot H L D \cdot H L A}}
$$

NDAA herein means Natural Disaster Annual Average. NDD refers to the Natural Disaster Damages, and NDOC refers to the Natural Disaster Occurrence by Country. DUR means Duration.

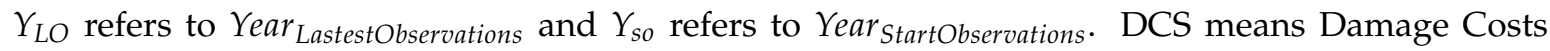
(thousand U.S. dollars) and HLD means Human Losses Deaths (person). HLA is Human Losses Affected (person).

Human losses from deaths, human losses affected, and damage costs were analyzed with regard to the annual average damage of natural disasters by countries. As shown in Figure 2, the scope of damage status was divided into eight segments. The damage status of the annual average damage of natural disasters by countries is shown as follows. (a) The unit of human losses due to deaths is person and 256,805 with the average of 1373 ranging from 0 to 113,787. (b) The unit of human losses affected is person and 77,691,384 with the average of 415,462 ranging from 0 to 29,171,908. (c) The unit of damage costs is thousand U.S. dollars and 32,945,272 with the average of 176,178 ranging from 0 to $8,645,196$. Specific annual damage status of natural disasters by countries is shown in Table A2. 

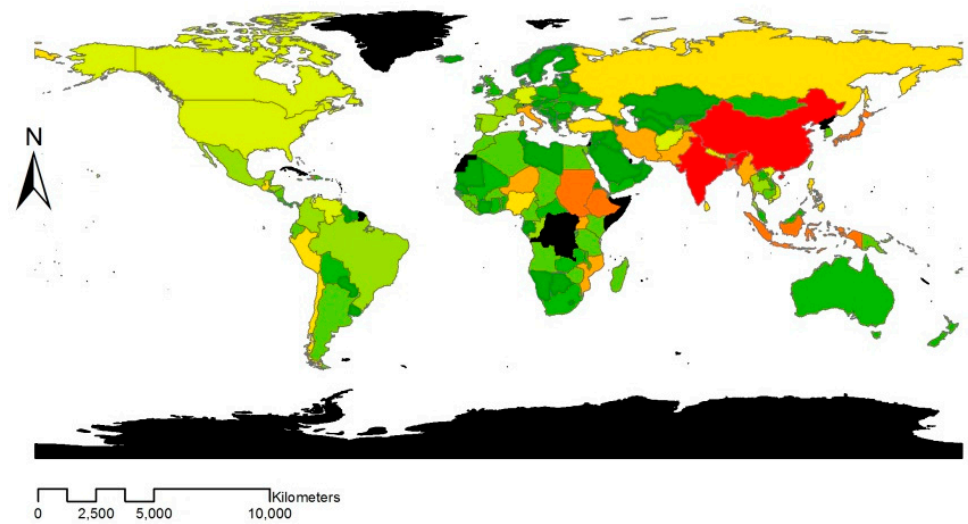

Human Losses Deaths(person)

\begin{tabular}{|c|c|c|c|c|}
\hline $0-19$ & $75-164$ & $306-467$ & $923-1925$ & $3752-26257$ \\
\hline $20-74$ & $165-305$ & $468-922$ & $1926-3751$ & $26258-113787$ \\
\hline
\end{tabular}

(a)
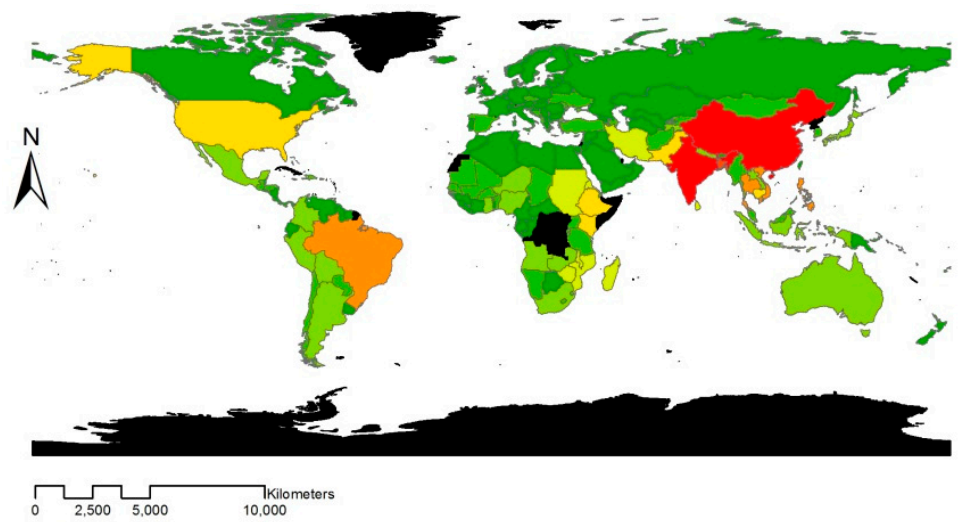

Human Losses Affected(person)

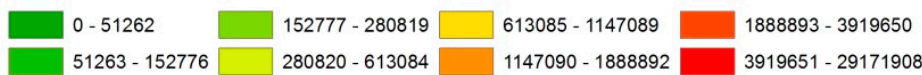

(b)

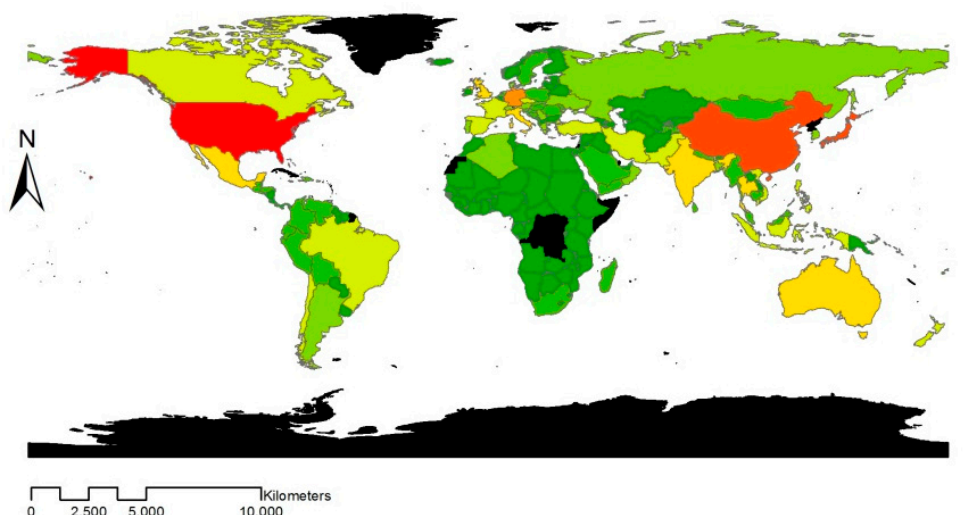

Damage Costs(thousand U.S. dollars)

\begin{tabular}{|c|c|c|c|}
\hline $0-28034$ & $93635-207320$ & $424267-856440$ & $2046470-4710401$ \\
\hline 28035 - 93634 & $207321-424266$ & $856441-2046469$ & $4710402-8645196$ \\
\hline
\end{tabular}

(c)

Figure 2. Current state of damage from natural disasters (1900-2017): (a) Human losses deaths by countries. (b) Human losses affected by countries. (c) National disaster damage costs by countries. 


\subsection{Indicators' Status by Country}

Damages by countries arisen from the occurrence of natural disasters affects damage sizes such as the current status of building urban and social infrastructures, national areas, and population, according to national economic levels. Indicators determining national economic levels include GDP, which is the annual total products by countries, announced by IMF, which is an international organization established for promoting economic development and global trading in 1961. Moreover, The World Factbook by CIA is offered as the area, which is a national basic indicator. Population is provided from World Population Prospects 2017 by UN.

This study analyzed GDP as economic indicators, areas, and population, as basic indicators by setting medium variables by countries for developing a damage prediction formula arisen from occurring natural disasters. Economic indicators and basic indicators by countries are indicators showing the variability of rising or decreasing by years. The present time was applied rather than the past average for developing a damage prediction formula.

Data in 2017 was analyzed regarding GDP, area, and population by countries. The scope by indicators was classified into eight and nine, as shown in Figure 3. The economic indicators and basic indicators status by countries are shown as follows. (a) GDP unit is billions U.S. dollars and 77,815 with the average of 416 ranging from 0.04 to 19,417. (b) Area unit is $\mathrm{km}^{2}$ and 132,951,506 with the average of 710,971 ranging from 26 to $17,098,242$. (c) The population unit is thousands people and $7,567,395$ with the average of 40,467 ranging from 11 to 1,415,046. The specific indicator status by countries is presented in Table A2.

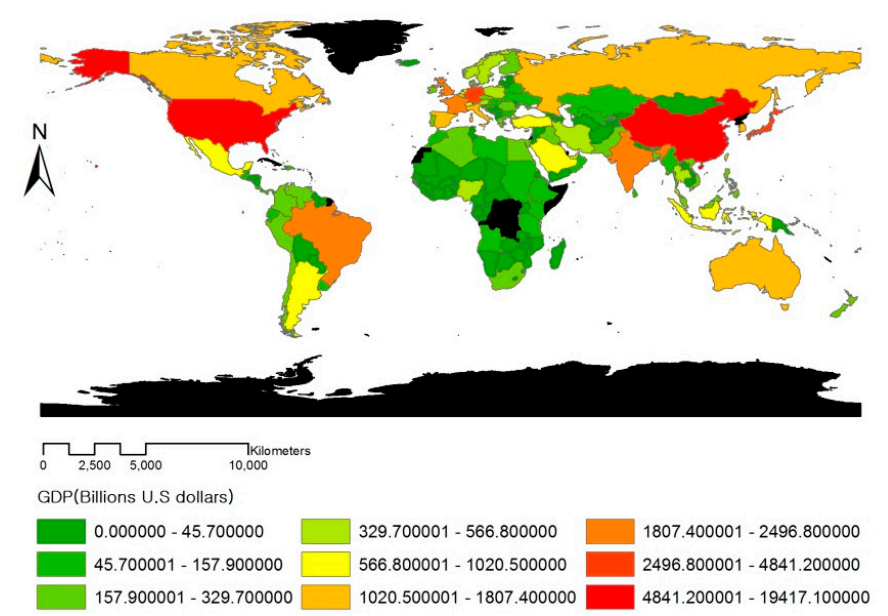

(a)

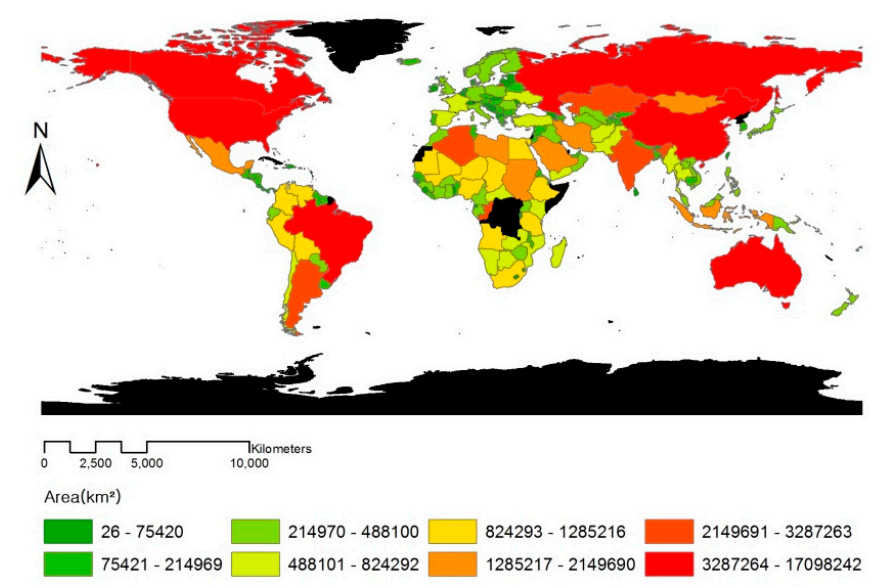

(b)

Figure 3. Cont. 

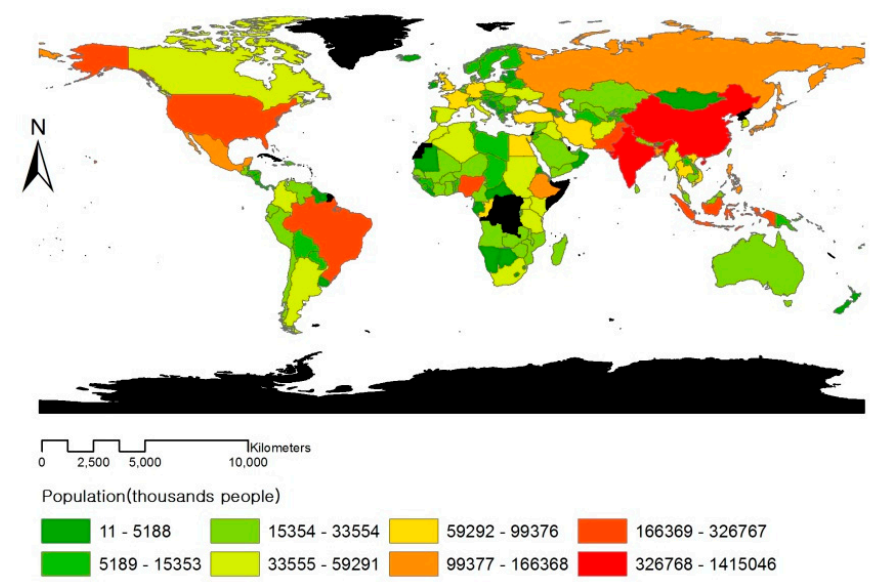

(c)

Figure 3. Current status on economic indicators and basic indicators (2017): (a) GDP by countries. (b) Areas by countries. (c) Population by countries.

\section{Results}

\subsection{Correlation Analysis}

For medium variables in order to develop a damage prediction formula of natural disasters, human losses from deaths, human losses affected, and damage costs were selected as a natural disaster damage status. GDP, area, and population were selected as an indicator status by countries. By analyzing the correlation of selected medium variables, it reviewed the appropriateness of developing a damage prediction formula. For a method of correlation analysis, correlation coefficients representing the standard on the distribution, size, and ranking of medium variables on Pearson, Kendall, and Spearman typically used in statistics were selected in this study. Results from analyzing correlation coefficients on the natural disaster damage status and the indicator status by countries are shown in Table 2.

Table 2. Correlation analysis of natural disaster damage status and indicator status by countries.

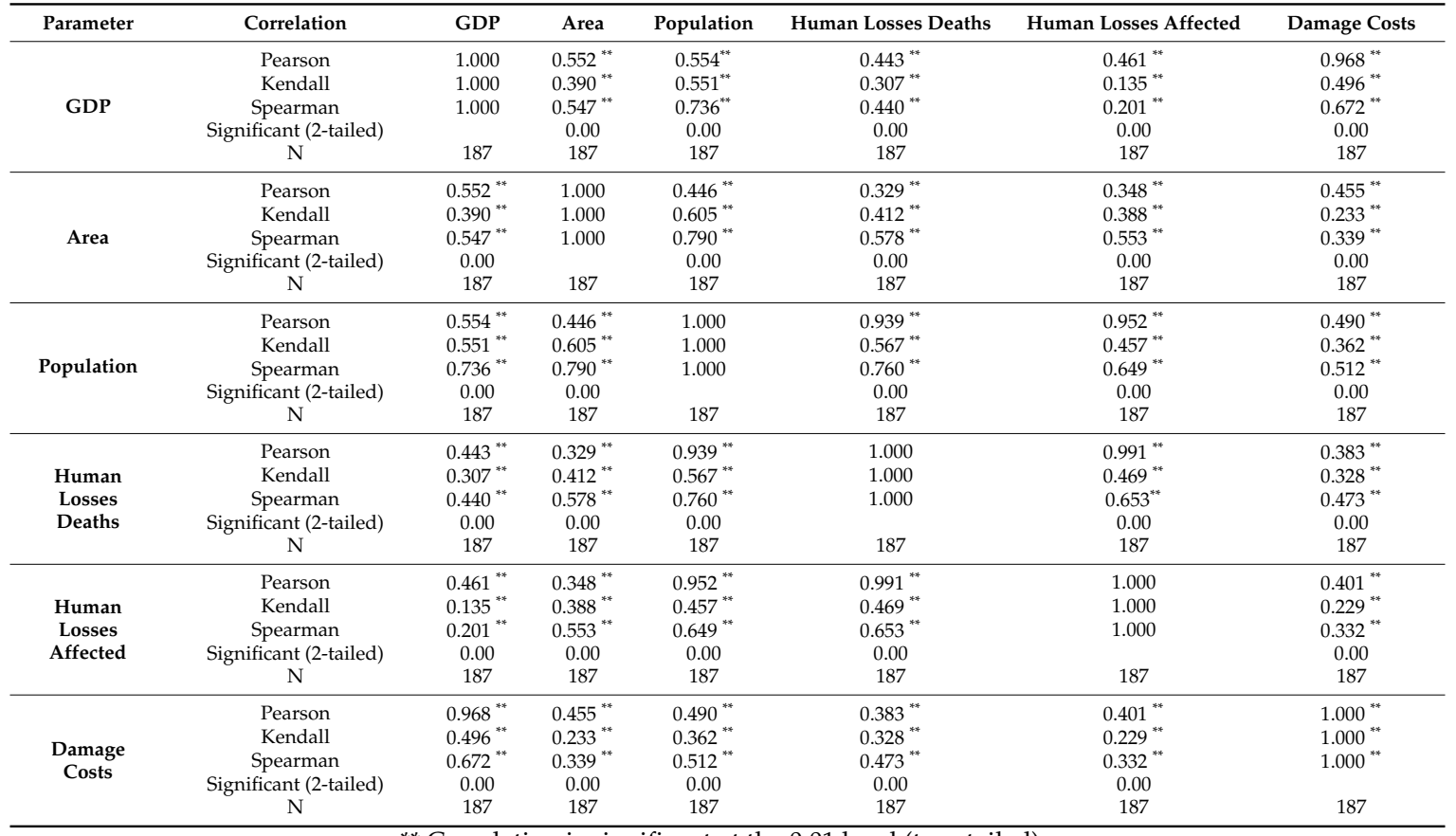

** Correlation is significant at the 0.01 level (two-tailed). 
The results from analyzing the correlation of medium variables showed a positive correlation in all conditions. Although the number of correlation coefficients by medium variables differs, according to the correlation analysis methods or data characteristics, six medium variables were identified as mutually significant. GDP, damage costs, population, human losses from death, population, and human losses affected showed a higher correlation with over 0.9 in the Pearson correlation regarding correlation coefficients by medium variables. In addition, the area showed a correlation coefficient ranging from 0.3 to 0.8 by medium variables regardless of analytical methods. Thus, the correlation of medium variables selected in this study turned out high. Significant results are considered to be drawn resulting from the interaction of medium variables when the natural disaster damage prediction formula is developed.

\subsection{Development of Damage Prediction Equation Considering Human Damage}

Multiple regression analysis was performed to develop a damage prediction formula on human losses when natural disasters occur. Human losses arisen from natural disasters are classified into human losses from deaths and human losses affected. By using results from correlation analysis by medium variables, the dependent variables and independent variables were set as shown in Section 4.1.

Multiple regression analysis was conducted by setting dependent variables of a medium variable as human losses from deaths and setting independent variable as GDP, area, and population for developing a damage prediction formula on human losses due to deaths. The results from regression analysis were calculated as shown in Table 3. The adjusted $\mathrm{R}^{2}$ was 0.893 . Three medium variables on human damage losses showed $89.3 \%$ higher explanatory powers. Moreover, the significance of using a formula as $\mathrm{F}=516.390$ of three dependent variables and independent variables, the level of significance as Sig $=0.000$ lesser than 0.05 was dramatically higher.

Table 3. Results from multiple regression analysis considering human losses from deaths.

\begin{tabular}{|c|c|c|c|c|c|c|}
\hline \multicolumn{7}{|c|}{ Model Summary } \\
\hline $\mathbf{R}$ & \multicolumn{2}{|c|}{ R Square } & \multicolumn{2}{|c|}{ Adjusted R Square } & \multicolumn{2}{|c|}{ Standard Error of the Estimate } \\
\hline $0.946^{\mathrm{a}}$ & \multicolumn{2}{|c|}{0.894} & \multicolumn{2}{|c|}{0.893} & \multicolumn{2}{|c|}{3340.632} \\
\hline \multicolumn{7}{|c|}{ ANOVA $^{b}$} \\
\hline & \multicolumn{2}{|c|}{ Sum of Squares } & df & Mean Square & $\mathbf{F}$ & Significance \\
\hline Regression & \multicolumn{2}{|c|}{17288446415.82} & 3 & 5762815471.940 & 516.390 & $0.000^{\mathrm{a}}$ \\
\hline Residual & \multicolumn{2}{|c|}{2042246931.16} & 183 & 11159819.296 & & \\
\hline Total & \multicolumn{2}{|c|}{19330693346.98} & 186 & & & \\
\hline \multicolumn{7}{|c|}{ Coefficients $^{\mathrm{b}}$} \\
\hline & \multicolumn{2}{|c|}{ Unstandardized Coefficients } & Standardized Coefficients & $\mathbf{t}$ & Significance & VIF \\
\hline & B & $\begin{array}{l}\text { Standard } \\
\text { Error }\end{array}$ & Beta & & & \\
\hline (Constant) & -975.7353 & 261.839 & & -3.726 & 0.000 & \\
\hline GDP & -0.4389 & 0.185 & -0.075 & -2.369 & 0.019 & 1.734 \\
\hline Area & 0.0004 & 0.00 & -0.084 & -2.846 & 0.005 & 1.499 \\
\hline Population & 0.0702 & 0.002 & 1.018 & 34.518 & 0.000 & 1.505 \\
\hline
\end{tabular}

It analyzed regression coefficients by each variable and multicollinearity indicators on dependent variables of damage prediction formula regarding human losses due to deaths. Regression coefficients by variables on independent variables turned out to be significant as the level of significance through the t-test was less than $1 \%$. However, the level of significance on the regression formula constant numbers was over $20 \%$. If constant numbers are elaborately adjusted, higher $\mathrm{R}^{2}$ is expected to be calculated. Multicollinearity shows the correlation with independent variables. Since VIF is set to less 
than 10, the regression coefficient B on independent variables can be trusted. Accordingly, a damage prediction formula on damage costs is shown as Formula (13).

$$
\mathrm{HLD}=-975.76353-0.4389 X_{1}+0.0004 X_{2}+0.0702 X_{3}
$$

HLD herein means Human Losses Deaths (person) and $X_{1}$ refers to the GDP (billions U.S. dollars). $X_{2}$ refers to the Area $\left(\mathrm{km}^{2}\right)$ and $X_{3}$ means the Population (thousands people).

Dependent variables of medium variables for developing damage prediction formula on damage costs set GDP, area, and population and multiple regression analysis was performed. Results from regression analysis were calculated, as shown in Table 4 . The adjusted $\mathrm{R}^{2}$ on the formula was 0.915 . Three medium variables on damage costs had $91.5 \%$ higher explanatory powers. Moreover, the significance of using a formula as $\mathrm{F}=664.390$ of three dependent variables and independent variables, the level of significance as Significance $=0.000$ lesser than 0.05 was dramatically higher.

Table 4. Results from multiple regression analysis considering human losses affected.

\begin{tabular}{|c|c|c|c|c|c|c|}
\hline \multicolumn{7}{|c|}{ Model Summary } \\
\hline $\mathbf{R}$ & \multicolumn{2}{|c|}{ R Square } & \multicolumn{2}{|c|}{ Adjusted R Square } & \multicolumn{2}{|c|}{ Standard Error of the Estimate } \\
\hline $0.957 \mathrm{a}$ & \multicolumn{2}{|c|}{0.916} & \multicolumn{2}{|l|}{0.915} & \multicolumn{2}{|c|}{763048.108} \\
\hline \multicolumn{7}{|c|}{ ANOVA $^{b}$} \\
\hline & \multicolumn{2}{|c|}{ Sum of Squares } & df & Mean Square & $\mathbf{F}$ & Significance \\
\hline Regression & \multicolumn{2}{|c|}{$1.161 \times 10^{15}$} & 3 & $3.869 \times 10^{14}$ & 664.504 & $0.000^{\mathrm{a}}$ \\
\hline Residual & \multicolumn{2}{|c|}{$1.066 \times 10^{14}$} & 183 & $5.822 \times 10^{11}$ & & \\
\hline Total & \multicolumn{2}{|c|}{$1.267 \times 10^{15}$} & 186 & & & \\
\hline \multicolumn{7}{|c|}{ Coefficients $^{b}$} \\
\hline & \multicolumn{2}{|c|}{ Unstandardized Coefficients } & Standardized Coefficients & $\mathbf{t}$ & Significance & VIF \\
\hline & B & $\begin{array}{l}\text { Standard } \\
\text { Error }\end{array}$ & Beta & & & \\
\hline (Constant) & -205644.9682 & 59807.681 & & -3.438 & 0.001 & (Constant) \\
\hline GDP & -96.7326 & 42.312 & -0.065 & -2.286 & 0.023 & GDP \\
\hline Area & -0.0954 & 0.035 & -0.071 & -2.721 & 0.007 & Area \\
\hline Population & 18.0191 & 0.465 & 1.020 & 38.769 & 0.000 & Population \\
\hline
\end{tabular}

It analyzed regression coefficients by each variable and multicollinearity indicators on dependent variables of damage prediction formula regarding human losses affected. Regression coefficients by variables on independent variables turned out to be significant as the level of significance through t-test was less than $1 \%$. However, the level of significance on regression formula constant numbers was more than $20 \%$. If constant numbers are elaborately adjusted, higher $\mathrm{R}^{2}$ is expected to be calculated. Multicollinearity shows the correlation with independent variables. Since VIF is set to less than 10, the regression coefficient $B$ on independent variables can be trusted. Accordingly, a damage prediction formula on damage costs is shown as Formula (14).

$$
\mathrm{HLA}=-205644.9682-96.7326 X_{1}-0.0954 X_{2}+18.0191 X_{3}
$$

HLA in this formula means the Human Losses Affected (person) and $X_{1}$ refers to GDP (billions U.S. dollars). $X_{2}$ means Area $\left(\mathrm{km}^{2}\right)$ and $X_{3}$ refers to the population (thousands people).

\subsection{Development of Damage Prediction Equation Considering Damage Costs}

When natural disasters occur, multiple regression analysis was conducted to develop a damage prediction equation considering damage costs. Damage costs from natural disasters set dependent variables and independent variables by using results from correlation analysis by medium variables, as shown in Section 4.1. 
Dependent variables of medium variables for developing the damage prediction formula on damage costs set GDP, area, and population. Multiple regression analysis was performed. The results from regression analysis were calculated, as shown in Table 5 . The adjusted $R^{2}$ on the formula was 0.946 . Three medium variables on damage costs had $94.6 \%$ higher explanatory powers. Moreover, the significance of using a formula as $\mathrm{F}=1088.215$ of three dependent variables and independent variables while the level of significance as Significance $=0.000$ lesser than 0.05 was dramatically higher.

Table 5. Results from multiple US regression analysis of damage costs.

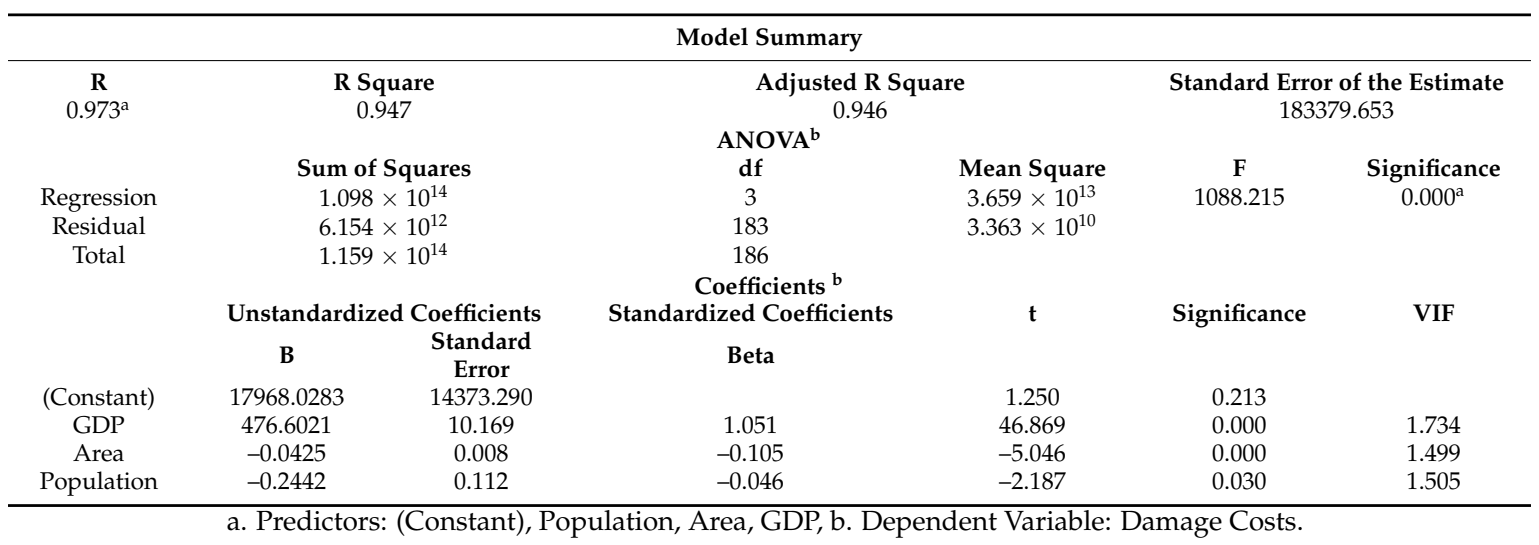

It analyzed regression coefficients by each variable and multicollinearity indicators on dependent variables of the damage prediction formula regarding damage costs. Regression coefficients by variables on independent variables turned out significant since the level of significance through the t-test was less than $1 \%$. However, the level of significance on regression formula constant numbers was more than $20 \%$. If constant numbers are elaborately adjusted, higher $\mathrm{R}^{2}$ is expected to be calculated. Multicollinearity shows the correlation with independent variables. As VIF is set to less than 10, the regression coefficient $B$ on independent variables can be trusted. Accordingly, a damage prediction formula on damage costs is shown in Formula (15).

$$
\mathrm{DCS}=17968.0283+476.6021 X_{1}-0.0425 X_{2}-0.2442 X_{3}
$$

DCS in this case means Damage Costs (thousand U.S. dollars). $X_{1}, X_{2}$, and $X_{3}$ refer to GDP (billions U.S. dollars), Area $\left(\mathrm{km}^{2}\right)$, and Population (thousands people), respectively.

\section{Discussion}

This study developed the damage prediction formula by considering economic indicators among natural disasters. Natural disasters produce the difference of damage sizes, according to the effects of society, economy, and geography even if the same disaster [7,14,23,29]. Earlier studies were mainly conducted to calculate damage costs of each disaster and develop damage prediction functions rather than studying national disaster management $[37,38,41]$. However, quantitative standards are needed to obtain the size of budgets or relief aids annually planned on comprehensive natural disaster rather than predicting individual disaster damage in terms of disaster management by countries.

This study developed a damage prediction formula on human losses due to deaths, human losses affected, and damage costs of natural disasters and three independent variables of economic indicators by countries such as GDP, population, and area, which were applied in calculating these variables. Adjusted $\mathrm{R}^{2}$ of the damage prediction formula showed that human losses from deaths mean 0.893, human losses affected mean 0.915 , and damage costs mean 0.946 in which higher significance was analyzed. Although previously performed human losses and GDP damage prediction formula were proposed, adjusted $R^{2}$ was inefficient ranging from 0.09 to 0.35 . Since regression analysis proposed a U-shaped correlation instead of a linear correlation, setting medium variables and methods in this 
study were appropriate. In addition, there was no significant difference in the correlation of R2 with the calculation formula of various parameters and the formula of GDP. Therefore, it is judged that the application of many parameters does not lead to accurate results $[14,15,17]$. More data needs to be investigated and built up to be applied in a variety of disasters or countries as single independent variables up to five variables of damage costs and the damage function formula are applied. In addition, only damage costs on the single occurrence by disaster types are calculated, yet quantitative data of budgets and relief aids for disaster management by countries were not analyzed [38-42].

The damage prediction formula in this study is differently applied as units of medium variables, which are human losses and damage costs. The unit of calculation results is person in case of human losses deaths and human losses affected, while thousands of people standard is needed for a national population. Calculating results are thousand U.S. dollars regarding damage costs, while billions U.S. dollars standard is applied in GDP. This mismatch of units by medium variables is assumed to be the limitation of national sizes arisen from data on human losses, damage costs, GDP, population, and area among the world. For further research tasks, it aims to classify grades according to the level of development by countries and developed an estimation formula, according to the annual damage status and the change of economic indicators. If the annual damage status and economic indicators are considered, quantitative indicators for the past, present, and future disaster management, according to the level of national development, are expected to be calculated.

\section{Conclusions}

This study aimed to consider economic indicators and damage status among natural disasters from 1900 to 2017 in 187 countries, and develop a damage prediction formula of disaster management by countries. For global natural disaster data, this study employed GDP, which is gross domestic product, from EM-DAT operated by CRED from IMF, World Population Prospects 2018 released by the $\mathrm{UN}$, and The World Factbook released from CIA on areas.

Medium variables for developing natural disaster damage prediction formula include human losses from deaths, human losses affected, and damage costs of damage status. Economic indicators by countries and basic indicators include GDP, population, and areas. In total, six medium variables were selected. Damage status of natural disasters considered the number of natural disasters during the period of disaster and calculated average damage costs incurred. Economic indicators and basic indicators were applied based on 2017. Correlation analysis by medium variables was conducted on Pearson, Kendall, and Spearman. Positive correlations were shown in all conditions. Each medium variable and correlation was analyzed to be significant.

A damage prediction formula of natural disaster was analyzed by using multiple regression analysis to calculate annual average damage prediction by applying GDP, population, and areas on human losses from deaths, human losses affected, and damage costs by countries. For a damage prediction formula on human losses due to deaths, the adjusted $\mathrm{R}^{2}$ turned out 0.893 , the level of significance was less than $1 \%$, and VIF was less than 10 . Thus, the significance of using the formula was high. A formula on human losses from deaths is summarized as HLD $=-975.76353-0.4389 X_{1}+0.0004 X_{2}+0.0702 X_{3}$. For a damage prediction formula on the human losses affected, the adjusted $R^{2}$ was 0.915 , the level of significance was less than $1 \%$, and VIF was less than 10. Thus, the significance of using the formula was high. A formula on human losses affected is summarized as HLA $=-205644.9682-96.7326 X_{1}-0.0954 X_{2}+18.0191 X_{3}$. For the damage prediction formula on damage costs, the adjusted $R^{2}$ turned out to be 0.946 and the level of significance on independent variables was less than $1 \%$. The level of significance on constant numbers is over $20 \%$ and VIF was less than 10 . Thus, the significance of using the formula was high. A formula on damage costs is DCS $=17968.0283+476.6021 X_{1}-0.0425 X_{2}-0.2442 X_{3}$.

The result of this study is considered to be a formula that can be used continuously to predict the damage of natural disaster even in the economic development of the country. The statistical analysis can also predict the damage of natural disasters even in the fluctuation of economy, population, and 
area by country. There are limitations in applying various parameters such as education, consumption, and facilities except economic indicators by country. However, in the previous studies, various parameters were applied to derive the relationship with natural disasters, but various results were obtained depending on the level of development of the country and the type of disaster. Therefore, the natural disaster damage prediction formula developed in this study is expected to calculate the quantitative damage status of potential natural disasters in accordance with economic indicators by countries, and used as response and preparation data for national disaster management.

Author Contributions: Y.S.S. carried out the survey of previous studies and wrote the draft of the manuscript. M.J.P. contributed to the manuscript by reviewing and discussing the methodology and analysis results of the damage prediction formula of a natural disaster considering economic indicators. Y.S.S. and M.J.P. put forward the concept of this article, led the development of methodology, and helped modify the manuscript. All authors contributed toward writing, reviewing, correcting in this manuscript.

Funding: This research was funded by the Ministry of the Interior and Safety of Korean government, grant number [MOIS-DP-2015-03].

Acknowledgments: This research was supported by a grant [MOIS-DP-2015-03] through the Disaster and Safety Management Institute funded by the Ministry of the Interior and Safety of the Korean government.

Conflicts of Interest: The authors declare that they have no conflicts of interest in the research. 


\section{Appendix A}

Table A1. Study area by country.

\begin{tabular}{|c|c|c|c|c|c|c|c|c|c|}
\hline No & Country & No & Country & No & Country & No & Country & No & Country \\
\hline 1 & Afghanistan & 39 & Cote d'Ivoire & 77 & Iran & 115 & Myanmar & 153 & South Africa \\
\hline 2 & Albania & 40 & Croatia & 78 & Iraq & 116 & Namibia & 154 & South Sudan \\
\hline 3 & Algeria & 41 & Cyprus & 79 & Ireland & 117 & Nepal & 155 & Spain \\
\hline 4 & Angola & 42 & Czech Republic & 80 & Israel & 118 & Netherlands & 156 & Sri Lanka \\
\hline 5 & Antigua and Barbuda & 43 & $\begin{array}{l}\text { Democratic Republic of the } \\
\text { Congo }\end{array}$ & 81 & Italy & 119 & New Zealand & 157 & Sudan \\
\hline 6 & Argentina & 44 & Denmark & 82 & Jamaica & 120 & Nicaragua & 158 & Suriname \\
\hline 7 & Armenia & 45 & Djibouti & 83 & Japan & 121 & Niger & 159 & Swaziland \\
\hline 8 & Australia & 46 & Dominica & 84 & Jordan & 122 & Nigeria & 160 & Sweden \\
\hline 9 & Austria & 47 & Dominican Republic & 85 & Kazakhstan & 123 & Norway & 161 & Switzerland \\
\hline 10 & Azerbaijan & 48 & Ecuador & 86 & Kenya & 124 & Oman & 162 & Syria \\
\hline 11 & Bahamas & 49 & Egypt & 87 & Kiribati & 125 & Pakistan & 163 & Taiwan \\
\hline 12 & Bahrain & 50 & El Salvador & 88 & Korea & 126 & Palau & 164 & Tajikistan \\
\hline 13 & Bangladesh & 51 & Equatorial Guinea & 89 & Kuwait & 127 & Panama & 165 & Tanzania \\
\hline 14 & Barbados & 52 & Eritrea & 90 & Kyrgyzstan & 128 & Papua New Guinea & 166 & Thailand \\
\hline 15 & Belarus & 53 & Estonia & 91 & $\begin{array}{c}\text { Lao People's Democratic } \\
\text { Republic }\end{array}$ & 129 & Paraguay & 167 & Timor-Leste \\
\hline 16 & Belgium & 54 & Ethiopia & 92 & Latvia & 130 & Peru & 168 & Togo \\
\hline 17 & Belize & 55 & Fiji & 93 & Lebanon & 131 & Philippines & 169 & Tonga \\
\hline 18 & Benin & 56 & Finland & 94 & Lesotho & 132 & Poland & 170 & Trinidad and Tobago \\
\hline 19 & Bhutan & 57 & France & 95 & Liberia & 133 & Portugal & 171 & Tunisia \\
\hline 20 & Bolivia & 58 & FYR Macedonia & 96 & Libya & 134 & Puerto Rico & 172 & Turkey \\
\hline 21 & Bosnia and Herzegovina & 59 & Gabon & 97 & Lithuania & 135 & Republic of Congo & 173 & Turkmenistan \\
\hline 22 & Botswana & 60 & Gambia & 98 & Luxembourg & 136 & Romania & 174 & Tuvalu \\
\hline 23 & Brazil & 61 & Georgia & 99 & Macao & 137 & Russian Federation & 175 & Uganda \\
\hline 24 & Brunei Darussalam & 62 & Germany & 100 & Madagascar & 138 & Rwanda & 176 & Ukraine \\
\hline 25 & Bulgaria & 63 & Ghana & 101 & Malawi & 139 & Saint Kitts and Nevis & 177 & United Arab Emirates \\
\hline 26 & Burkina Faso & 64 & Greece & 102 & Malaysia & 140 & Saint Lucia & 178 & United Kingdom \\
\hline 27 & Burundi & 65 & Grenada & 103 & Maldives & 141 & $\begin{array}{l}\text { Saint Vincent and the } \\
\text { Grenadines }\end{array}$ & 179 & United States of America \\
\hline 28 & Cabo Verde & 66 & Guatemala & 104 & Mali & 142 & Samoa & 180 & Uruguay \\
\hline 29 & Cambodia & 67 & Guinea & 105 & Marshall Islands & 143 & Sao Tome and Principe & 181 & Uzbekistan \\
\hline 30 & Cameroon & 68 & Guinea-Bissau & 106 & Mauritania & 144 & Saudi Arabia & 182 & Vanuatu \\
\hline 31 & Canada & 69 & Guyana & 107 & Mauritius & 145 & Senegal & 183 & Venezuela \\
\hline 32 & Central African Republic & 70 & Haiti & 108 & Mexico & 146 & Serbia & 184 & Vietnam \\
\hline 33 & Chad & 71 & Honduras & 109 & Micronesia & 147 & Seychelles & 185 & Yemen \\
\hline 34 & Chile & 72 & Hong Kong SAR & 110 & Moldova & 148 & Sierra Leone & 186 & Zambia \\
\hline 35 & China & 73 & Hungary & 111 & Mongolia & 149 & Singapore & 187 & Zimbabwe \\
\hline 36 & Colombia & 74 & Iceland & 112 & Montenegro & 150 & Slovakia & & \\
\hline 37 & Comoros & 75 & India & 113 & Morocco & 151 & Slovenia & & \\
\hline 38 & Costa Rica & 76 & Indonesia & 114 & Mozambique & 152 & Solomon Islands & & \\
\hline
\end{tabular}


Table A2. Annual current state of damage from natural disasters and economic indicators and basic indicators by country.

\begin{tabular}{|c|c|c|c|c|c|c|}
\hline Country Name & GDP (Billions) & $\begin{array}{c}\text { Area } \\
\left(\mathrm{km}^{2}\right)\end{array}$ & $\begin{array}{c}\text { Population } \\
\text { (thousands people) }\end{array}$ & $\begin{array}{c}\text { Human Losses Deaths } \\
\text { (person) }\end{array}$ & $\begin{array}{l}\text { Human Losses Affected } \\
\text { (person) }\end{array}$ & $\begin{array}{c}\text { Damage Costs } \\
\text { (thousand U.S. dollars) }\end{array}$ \\
\hline Afghanistan & 20.6 & 652,230 & 36,373 & 380 & 151,400 & $9,426.9$ \\
\hline Albania & 12.3 & 28,748 & 2,934 & 4 & 81,879 & 658.3 \\
\hline Algeria & 173.9 & $2,381,741$ & 42,008 & 109 & 21,389 & $109,396.7$ \\
\hline Angola & 122.4 & $1,246,700$ & 30,774 & 164 & 195,955 & 324.3 \\
\hline Antigua and Barbuda & 1.5 & 443 & 103 & 0 & 1866 & $11,670.6$ \\
\hline Argentina & 628.9 & $2,780,400$ & 44,689 & 157 & 203,752 & $156,586.6$ \\
\hline Armenia & 10.7 & 29,743 & 2934 & 0 & 19,795 & $10,072.7$ \\
\hline Australia & $1,359.7$ & $7,741,220$ & 24,772 & 28 & 205,784 & $667,795.9$ \\
\hline Austria & 383.5 & 83,871 & 8752 & 12 & 1100 & $100,348.0$ \\
\hline Azerbaijan & 38.6 & 86,600 & 9924 & 4 & 143,071 & $11,733.3$ \\
\hline Bahamas & 9.2 & 13,880 & 399 & 1 & 447 & $36,359.8$ \\
\hline Bahrain & 34.3 & 760 & 1,567 & 111 & 0 & 0.0 \\
\hline Bangladesh & 248.9 & 148,460 & 166,368 & 26,257 & $3,919,650$ & $173,796.3$ \\
\hline Barbados & 4.8 & 430 & 286 & 1 & 173 & 1701.6 \\
\hline Belarus & 54.7 & 207,600 & 9452 & 3 & 6384 & 7107.2 \\
\hline Belgium & 462.7 & 30,528 & 11,499 & 24 & 127 & $20,361.5$ \\
\hline Belize & 1.8 & 22,966 & 382 & 22 & 3,913 & $7,436.1$ \\
\hline Benin & 8.8 & 112,622 & 11,486 & 33 & 115,689 & 190.8 \\
\hline Bhutan & 2.3 & 38,394 & 817 & 11 & 3236 & 129.6 \\
\hline Bolivia & 39.3 & $1,098,581$ & 11,216 & 42 & 164,184 & $72,648.4$ \\
\hline Bosnia and Herzegovina & 16.8 & 51,197 & 3504 & 3 & 83,186 & $48,328.2$ \\
\hline Botswana & 15.6 & 581,730 & 2333 & 13 & 29,369 & 982.1 \\
\hline Brazil & $2,140.9$ & $8,515,770$ & 210,868 & 184 & $1,507,355$ & $321,219.7$ \\
\hline Brunei Darussalam & 12.3 & 5765 & 434 & 0 & 0 & $2,000.0$ \\
\hline $\begin{array}{l}\text { Bulgaria } \\
\text { a }\end{array}$ & 52.3 & 110,879 & 7037 & 4 & 800 & $16,139.8$ \\
\hline Burkina Faso & 12.3 & 274,200 & 19,752 & 160 & 122,876 & 1677.6 \\
\hline Burundi & 3.4 & 27,830 & 11,216 & 29 & 114,809 & 375.0 \\
\hline Cabo Verde & 1.6 & 4033 & 553 & 735 & 769 & 35.3 \\
\hline Cambodia & 21.0 & 181,035 & 16,246 & 82 & 764,997 & 51970.3 \\
\hline Cameroon & 29.5 & 475,440 & 24,678 & 128 & 22,436 & 110.6 \\
\hline Canada & $1,600.3$ & $9,984,670$ & 36,954 & 451 & 22,675 & $280,353.0$ \\
\hline Central African Republic & 2.0 & 622,984 & 4737 & 21 & 5133 & 2.8 \\
\hline Chad & 9.6 & $1,284,000$ & 15,353 & 96 & 104,295 & 871.8 \\
\hline Chile & 251.2 & 756,102 & 18,197 & 549 & 111,438 & $367,669.4$ \\
\hline China & $11,795.3$ & $9,596,960$ & $1,415,046$ & 113,787 & $29,171,908$ & $4,710,401.3$ \\
\hline Colombia & 306.4 & $1,138,910$ & 49,465 & 305 & 161,920 & $63,968.5$ \\
\hline Comoros & 0.7 & 2235 & 832 & 6 & 4,636 & 426.8 \\
\hline Costa Rica & 59.8 & 51,100 & 4953 & 21 & 17,787 & $12,593.4$ \\
\hline Cote d'Ivoire & 36.9 & 322,463 & 24,906 & 19 & 732 & 0.0 \\
\hline Croatia & 50.1 & 56,594 & 4165 & 39 & 945 & $38,579.5$ \\
\hline Cyprus & 19.6 & 9251 & 1189 & 2 & 107 & 262.5 \\
\hline Czech Republic & 196.1 & 78,867 & 10,625 & 27 & 73,743 & $271,227.8$ \\
\hline Democratic Republic of the Congo & 41.1 & $2,344,858$ & 84,005 & 213 & 45,146 & 600.0 \\
\hline Denmark & 304.2 & 43,094 & 5754 & 1 & 0 & $136,753.7$ \\
\hline Djibouti & 2.1 & 23,200 & 971 & 10 & 55,357 & 168.2 \\
\hline Dominica & 0.5 & 751 & 74 & 24 & 2232 & $25,262.0$ \\
\hline
\end{tabular}


Table A2. Cont.

\begin{tabular}{|c|c|c|c|c|c|c|}
\hline Country Name & GDP (Billions) & $\begin{array}{c}\text { Area } \\
\left(\mathrm{km}^{2}\right)\end{array}$ & $\begin{array}{c}\text { Population } \\
\text { (thousands people) }\end{array}$ & $\begin{array}{c}\text { Human Losses Deaths } \\
\text { (person) }\end{array}$ & $\begin{array}{l}\text { Human Losses Affected } \\
\text { (person) }\end{array}$ & $\begin{array}{c}\text { Damage Costs } \\
\text { (thousand U.S. dollars) }\end{array}$ \\
\hline Dominican Republic & 76.9 & 48,670 & 10,883 & 66 & 85,847 & $34,029.9$ \\
\hline Ecuador & 97.4 & 283,561 & 16,863 & 134 & 46,799 & $51,055.3$ \\
\hline Egypt & 236.5 & $1,001,450$ & 99,376 & 133 & 4139 & $16,274.7$ \\
\hline El Salvador & 27.5 & 21,041 & 6,412 & 66 & 38,967 & $57,869.1$ \\
\hline Equatorial Guinea & 11.7 & 28,051 & 1314 & 15 & 946 & 0.0 \\
\hline Eritrea & 6.1 & 117,600 & 5188 & 0 & 351,418 & 322.8 \\
\hline Estonia & 23.4 & 45,228 & 1307 & 1 & 13 & $16,250.0$ \\
\hline Ethiopia & 78.4 & $1,104,300$ & 107,535 & 3,751 & 725,147 & $13,683.7$ \\
\hline Fiji & 4.9 & 18,274 & 912 & 7 & 23,337 & $14,927.1$ \\
\hline Finland & 234.5 & 338,145 & 5543 & 0 & 25 & 625.0 \\
\hline France & 2420.4 & 643,801 & 65,233 & 233 & 38,007 & $399,501.8$ \\
\hline FYR Macedonia & 11.0 & 25,713 & 2085 & 3 & 51,262 & $16,366.5$ \\
\hline Gabon & 14.2 & 267,667 & 2068 & 5 & 4435 & 0.0 \\
\hline Gambia & 1.0 & 11,300 & 2164 & 4 & 13,559 & 6.6 \\
\hline Georgia & 13.7 & 69,700 & 3907 & 3 & 35,518 & $28,034.2$ \\
\hline Germany & $3,423.3$ & 357,022 & 82,293 & 347 & 20,595 & $2,046,468.9$ \\
\hline Ghana & 42.8 & 238,533 & 29,464 & 22 & 221,455 & $1,522.8$ \\
\hline Greece & 193.1 & 131,957 & 11,142 & 28 & 11,900 & $145,918.4$ \\
\hline Grenada & 1.1 & 344 & 108 & 1 & 1275 & $18,843.8$ \\
\hline Guatemala & 70.9 & 108,889 & 17,245 & 728 & 111,744 & $38,176.4$ \\
\hline Guinea & 6.9 & 245,857 & 13,053 & 107 & 12,760 & 0.0 \\
\hline Guinea-Bissau & 1.2 & 36,125 & 1907 & 30 & 2,998 & 0.0 \\
\hline Guyana & 3.6 & 214,969 & 782 & 1 & 27,197 & $14,425.5$ \\
\hline Haiti & 7.9 & 27,750 & 11,113 & 2293 & 177,206 & $104,567.6$ \\
\hline Honduras & 21.8 & 112,090 & 9417 & 277 & 62,888 & $50,328.9$ \\
\hline Hong Kong SAR & 332.3 & 1,108 & 7429 & 219 & 1310 & $11,928.1$ \\
\hline Hungary & 125.3 & 93,028 & 9689 & 22 & 5349 & $40,841.7$ \\
\hline Iceland & 23.0 & 103,000 & 338 & 1 & 152 & $1,868.1$ \\
\hline India & $2,454.5$ & $3,287,263$ & $1,354,052$ & 77,390 & $20,345,983$ & $789,199.2$ \\
\hline Indonesia & $1,020.5$ & $1,904,569$ & 266,795 & 2,179 & 276,959 & $268,204.8$ \\
\hline Iran & 368.5 & $1,648,195$ & 82,012 & 1,439 & 411,553 & $225,914.6$ \\
\hline Iraq & 189.4 & 438,317 & 39,340 & 3 & 16,610 & 957.8 \\
\hline Ireland & 294.2 & 70,273 & 4,804 & 1 & 179 & $19,372.9$ \\
\hline Israel & 340.0 & 20,770 & 8453 & 2 & 44,365 & $31,973.4$ \\
\hline Italy & $1,807.4$ & 301,340 & 59,291 & 1,247 & 35,632 & $856,440.4$ \\
\hline Jamaica & 14.3 & 10,991 & 2899 & 23 & 24,538 & $24,306.1$ \\
\hline Japan & $4,841.2$ & 377,915 & 127,185 & 2,075 & 167,674 & $3,902,597.5$ \\
\hline Jordan & 40.5 & 89,342 & 9904 & 8 & 4675 & $5,307.9$ \\
\hline Kazakhstan & 157.9 & $2,724,900$ & 18,404 & 9 & 32,066 & $11,422.8$ \\
\hline Kenya & 75.1 & 580,367 & 50,951 & 125 & $1,147,089$ & 4812.7 \\
\hline Kiribati & 0.2 & 811 & 118 & 0 & 1,974 & 0.0 \\
\hline Korea & 1498.1 & 99,720 & 51,164 & 110 & 83,383 & $199,308.0$ \\
\hline Kuwait & 127.0 & 17,818 & 4197 & 0 & 29 & 0.0 \\
\hline Kyrgyzstan & 6.9 & 199,951 & 6133 & 18 & 87,537 & 8375.4 \\
\hline Lao People's Democratic Republic & 15.0 & 236,800 & 6961 & 28 & 198,207 & $11,107.9$ \\
\hline Latvia & 27.8 & 64,589 & 1930 & 7 & 7 & $23,250.0$ \\
\hline
\end{tabular}


Table A2. Cont.

\begin{tabular}{|c|c|c|c|c|c|c|}
\hline Country Name & GDP (Billions) & $\begin{array}{c}\text { Area } \\
\left(\mathrm{km}^{2}\right)\end{array}$ & $\begin{array}{c}\text { Population } \\
\text { (thousands people) }\end{array}$ & $\begin{array}{c}\text { Human Losses Deaths } \\
\text { (person) }\end{array}$ & $\begin{array}{l}\text { Human Losses Affected } \\
\text { (person) }\end{array}$ & $\begin{array}{c}\text { Damage Costs } \\
\text { (thousand U.S. dollars) }\end{array}$ \\
\hline Lebanon & 53.9 & 10,400 & 6094 & 10 & 18,442 & $2,704.9$ \\
\hline Lesotho & 2.4 & 30,355 & 2263 & 3 & 79,869 & 20.4 \\
\hline Liberia & 2.2 & 111,369 & 4854 & 148 & 43,078 & $1,270.3$ \\
\hline Libya & 54.4 & $1,759,540$ & 6471 & 5 & 29 & 674.3 \\
\hline Lithuania & 42.8 & 65,300 & 2876 & 5 & 37,143 & $14,932.0$ \\
\hline Luxembourg & 60.0 & 2,586 & 590 & 6 & 0 & $15,035.7$ \\
\hline Macao & 45.7 & 28 & 632 & 0 & 167 & $56,800.0$ \\
\hline Madagascar & 10.4 & 587,041 & 26,263 & 100 & 347,624 & $4,6436.0$ \\
\hline Malawi & 6.2 & 118,484 & 19,165 & 61 & 613,084 & 8833.1 \\
\hline Malaysia & 309.9 & 329,847 & 32,042 & 27 & 73,918 & $44,322.7$ \\
\hline Maldives & 3.6 & 298 & 444 & 10 & 1,928 & $14,885.3$ \\
\hline Mali & 14.3 & $1,240,192$ & 19,108 & 38 & 67,701 & 0.0 \\
\hline Marshall Islands & 0.2 & 181 & 53 & 0 & 1382 & 196.0 \\
\hline Mauritania & 5.1 & $1,030,700$ & 4540 & 2 & 106,530 & 569.4 \\
\hline Mauritius & 12.2 & 2040 & 1268 & 2 & 19,111 & $14,877.3$ \\
\hline Mexico & 987.3 & $1,964,375$ & 130,759 & 267 & 230,682 & $593,654.0$ \\
\hline Micronesia & 0.3 & 702 & 106 & 3 & 5,869 & 583.3 \\
\hline Moldova & 7.4 & 33,851 & 4041 & 5 & 152,776 & $42,114.9$ \\
\hline Mongolia & 10.3 & $1,564,116$ & 3122 & 25 & 76,182 & $32,789.6$ \\
\hline Montenegro & 4.2 & 13,812 & 629 & 0 & 1144 & 0.0 \\
\hline Morocco & 105.6 & 446,550 & 36,192 & 135 & 33,290 & $18,818.0$ \\
\hline Mozambique & 11.2 & 799,380 & 30,529 & 1714 & 557,839 & $18,542.7$ \\
\hline Myanmar & 72.4 & 676,578 & 53,856 & 1263 & 83,202 & $41,960.5$ \\
\hline Namibia & 11.8 & 824,292 & 2,588 & 15 & 90,509 & $5,430.3$ \\
\hline Nepal & 23.3 & 147,181 & 29,624 & 394 & 208,241 & $77,751.8$ \\
\hline Netherlands & 762.7 & 41,543 & 17,084 & 63 & 8833 & $88,667.2$ \\
\hline New Zealand & 198.0 & 268,838 & 4750 & 74 & 6704 & $307,300.4$ \\
\hline Nicaragua & 13.7 & 130,370 & 6285 & 154 & 40,911 & $24,553.2$ \\
\hline Niger & 7.7 & $1,267,000$ & 22,311 & 1700 & 258,194 & 2365.6 \\
\hline Nigeria & 400.6 & 923,768 & 195,875 & 573 & 280,819 & $14,663.8$ \\
\hline Norway & 392.0 & 323,802 & 5353 & 1 & 88 & 7407.9 \\
\hline Oman & 71.3 & 309,500 & 4830 & 7 & 807 & $126,146.3$ \\
\hline Pakistan & 305.0 & 796,095 & 200,814 & 1925 & 995,626 & $308,793.1$ \\
\hline Palau & 0.3 & 459 & 22 & 0 & 625 & 0.0 \\
\hline Panama & 59.5 & 75,420 & 4163 & 7 & 6957 & 5825.0 \\
\hline Papua New Guinea & 21.2 & 462,840 & 8418 & 84 & 48,654 & 3104.7 \\
\hline Paraguay & 28.7 & 406,752 & 6897 & 6 & 67,429 & 2843.6 \\
\hline Peru & 207.1 & $1,285,216$ & 32,552 & 922 & 221,854 & $60,997.6$ \\
\hline Philippines & 329.7 & 300,000 & 106,512 & 619 & $1,888,892$ & $233,112.3$ \\
\hline Poland & 482.9 & 312,685 & 38,105 & 26 & 4212 & $93,633.9$ \\
\hline Portugal & 202.8 & 92,090 & 10,291 & 78 & 4089 & $146,062.2$ \\
\hline Puerto Rico & 99.7 & 9104 & 3659 & 15 & 9302 & $717,280.0$ \\
\hline Republic of Congo & 8.3 & 342,000 & 5400 & 19 & 4054 & 1.3 \\
\hline Romania & 189.8 & 238,391 & 19,581 & 45 & 18,668 & $55,590.2$ \\
\hline Russian Federation & 1560.7 & $17,098,242$ & 143,965 & 616 & 44,289 & $112,730.0$ \\
\hline Rwanda & 8.9 & 26,338 & 12,501 & 22 & 140,238 & 0.2 \\
\hline Saint Kitts and Nevis & 1.0 & 261 & 56 & 0 & 159 & 7832.2 \\
\hline
\end{tabular}


Table A2. Cont.

\begin{tabular}{|c|c|c|c|c|c|c|}
\hline Country Name & GDP (Billions) & $\begin{array}{c}\text { Area } \\
\left(\mathrm{km}^{2}\right)\end{array}$ & $\begin{array}{c}\text { Population } \\
\text { (thousands people) }\end{array}$ & $\begin{array}{c}\text { Human Losses Deaths } \\
\text { (person) }\end{array}$ & $\begin{array}{l}\text { Human Losses Affected } \\
\text { (person) }\end{array}$ & $\begin{array}{c}\text { Damage Costs } \\
\text { (thousand U.S. dollars) }\end{array}$ \\
\hline Saint Lucia & 1.4 & 616 & 180 & 1 & 5476 & 2442.9 \\
\hline Saint Vincent and the Grenadines & 0.8 & 389 & 110 & 15 & 822 & 1622.6 \\
\hline Samoa & 0.8 & 2,831 & 198 & 9 & 7659 & $15,694.8$ \\
\hline Sao Tome and Principe & 0.4 & 964 & 209 & 9 & 4148 & 0.0 \\
\hline Saudi Arabia & 707.4 & $2,149,690$ & 33,554 & 12 & 606 & $31,518.5$ \\
\hline Senegal & 15.4 & 196,722 & 16,294 & 14 & 97,034 & $4,011.5$ \\
\hline Serbia & 37.7 & 77,474 & 8762 & 9 & 19,136 & $207,320.2$ \\
\hline Seychelles & 1.5 & 455 & 95 & 0 & 1301 & 2050.0 \\
\hline Sierra Leone & 4.1 & 71,740 & 7720 & 156 & 7448 & 781.4 \\
\hline Singapore & 291.9 & 697 & 5792 & 2 & 849 & 0.0 \\
\hline Slovakia & 89.1 & 49,035 & 5450 & 10 & 2829 & $37,409.5$ \\
\hline Slovenia & 43.5 & 20,273 & 2081 & 18 & 3936 & $44,235.3$ \\
\hline Solomon Islands & 1.2 & 28,896 & 623 & 9 & 5180 & 581.4 \\
\hline South Africa & 317.6 & $1,219,090$ & 57,398 & 23 & 219,750 & $55,949.7$ \\
\hline South Sudan & 4.8 & 644,329 & 12,919 & 49 & $1,006,103$ & 0.0 \\
\hline Spain & 1232.4 & 505,370 & 46,397 & 266 & 105,370 & $424,266.1$ \\
\hline Sri Lanka & 84.0 & 65,610 & 20,950 & 655 & 502,821 & $73,366.6$ \\
\hline Sudan & 115.9 & $1,861,484$ & 41,512 & 2096 & 443,066 & 7156.4 \\
\hline Suriname & 3.6 & 163,820 & 568 & 0 & 904 & 1.3 \\
\hline Swaziland & 3.9 & 17,364 & 1391 & 21 & 89,478 & 1645.3 \\
\hline Sweden & 507.0 & 450,295 & 9983 & 1 & 11 & $83,073.7$ \\
\hline Switzerland & 659.4 & 41,277 & 8544 & 21 & 148 & $122,384.5$ \\
\hline Syria & 24.6 & 185,180 & 18,284 & 4 & 38,409 & 898.0 \\
\hline Taiwan & 566.8 & 35,980 & 23,694 & 197 & 35,277 & $198,705.5$ \\
\hline Tajikistan & 7.2 & 144,100 & 9107 & 79 & 241,980 & $64,478.0$ \\
\hline Tanzania & 51.2 & 947,300 & 59,091 & 89 & 121,856 & 3998.2 \\
\hline Thailand & 432.9 & 513,120 & 69,183 & 239 & $1,707,325$ & $83,4014.4$ \\
\hline Timor-Leste & 2.7 & 14,874 & 1324 & 2 & 8486 & 250.0 \\
\hline Togo & 4.6 & 56,785 & 7991 & 23 & 22,258 & 13.5 \\
\hline Tonga & 0.4 & 747 & 109 & 0 & 2880 & 1731.0 \\
\hline Trinidad and Tobago & 21.7 & 5128 & 1373 & 1 & 682 & 822.1 \\
\hline Tunisia & 40.3 & 163,610 & 11,659 & 16 & 9650 & 7226.2 \\
\hline Turkey & 793.7 & 783,562 & 81,917 & 801 & 77,849 & $239,218.3$ \\
\hline Turkmenistan & 42.4 & 488,100 & 5851 & 1 & 53 & $12,483.8$ \\
\hline $\begin{array}{l}\text { Tuvalu } \\
\text { Tut }\end{array}$ & $\begin{array}{l}2+.4 \\
0.0\end{array}$ & 26 & 11 & 0 & 140 & $\begin{array}{c}1,+00.0 \\
0.0\end{array}$ \\
\hline Uganda & 27.2 & 241,038 & 44,271 & 1750 & 55,397 & 685.2 \\
\hline Ukraine & 95.9 & 603,550 & 44,009 & 57 & 109,685 & $128,831.3$ \\
\hline United Arab Emirates & 407.2 & 83,600 & 9542 & 0 & 188 & 0.0 \\
\hline United Kingdom & 2496.8 & 243,610 & 66,574 & 26 & 11,629 & $566,472.4$ \\
\hline United States of America & $19,417.1$ & $9,833,517$ & 326,767 & 373 & 964,231 & $8,645,195.8$ \\
\hline Uruguay & 58.1 & 176,215 & 3470 & 1 & 5134 & 7196.1 \\
\hline Uzbekistan & 68.3 & 447,400 & 32,365 & 4 & 32,602 & 2500.0 \\
\hline Vanuatu & 0.8 & 12,189 & 282 & 5 & 6929 & 418.6 \\
\hline Venezuela & 251.6 & 912,050 & 32,381 & 467 & 16,517 & $54,319.8$ \\
\hline Vietnam & 215.8 & 331,210 & 96,491 & 411 & $1,450,242$ & $332,328.8$ \\
\hline Yemen & 27.2 & 527,968 & 28,915 & 43 & $\begin{array}{l}1,7+1,152 \\
22,152\end{array}$ & $67,092.6$ \\
\hline Zambia & 23.1 & 752,618 & 17,609 & 35 & 235,579 & 522.5 \\
\hline Zimbabwe & 15.3 & 390,757 & 16,913 & 161 & 469,882 & $24,132.6$ \\
\hline
\end{tabular}




\section{References}

1. Costanza, R.; Farley, J. Ecological economics of coastal disasters: Introduction to the special issue. Ecol. Econ. 2007, 63, 249-253. [CrossRef]

2. Alexander, L.V.; Zhang, X.; Peterson, T.C.; Caesar, J.; Gleason, B.; Klein Tank, A.M.G.; Haylock, M.; Collins, D.; Trewin, B.; Rahimzadeh, F.; et al. Global observed changes in daily climate extremes of temperature and precipitation. J. Geophys. Res. Atmos. 2006, 111. [CrossRef]

3. Easterling, D.R.; Meehl, G.A.; Parmesan, C.; Changnon, S.A.; Karl, T.R.; Mearns, L.O. Climate Extremes: Observations, Modeling, and Impacts. Science 2000, 289, 2068-2074. [CrossRef] [PubMed]

4. Kunkel, K.E.; Andsager, K.; Easterling, D.R. Long-Term Trends in Extreme Precipitation Events over the Conterminous United States and Canada. J. Clim. 1999, 12, 2515-2527. [CrossRef]

5. Moberg, A.; Jones, P.D.; Lister, D.; Walther, A.; Brunet, M.; Jacobeit, J.; Alexander, L.V.; Della-Marta, P.M.; Luterbacher, J.; Yiou, P.; et al. Indices for daily temperature and precipitation extremes in Europe analyzed for the period 1901-2000. J. Geophys. Res. Atmos. 2006, 111. [CrossRef]

6. Loayza, N.V.; Olaberría, E.; Rigolini, J.; Christiaensen, L. Natural Disasters and Growth: Going Beyond the Averages. World Dev. 2012, 40,1317-1336. [CrossRef]

7. Daniell, J.E.; Khazai, B.; Wenzel, F.; Vervaeck, A. The CATDAT damaging earthquakes database. Nat. Hazards Earth Syst. Sci. 2011, 11, 2235-2251. [CrossRef]

8. Pielke, R.A., Jr.; Landsea, C.W. Normalized Hurricane Damages in the United States: 1925-95. Weather Forecast. 1998, 13, 621-631. [CrossRef]

9. Kousky, C. Informing climate adaptation: A review of the economic costs of natural disasters. Energy Econ. 2014, 46, 576-592. [CrossRef]

10. Neumayer, E.; Barthel, F. Normalizing economic loss from natural disasters: A global analysis. Glob. Environ. Chang. 2011, 21, 13-24. [CrossRef]

11. Pielke, R.A.; Gratz, J.; Landsea, C.W.; Collins, D.; Saunders, M.A.; Musulin, R. Normalized Hurricane Damage in the United States: 1900-2005. Nat. Hazards Rev. 2008, 9, 29-42. [CrossRef]

12. Mendelsohn, R.; Saher, G. The Global Impact of Climate Change on Extreme Events; The word bank: Washington, DC, USA, 2011.

13. Wildavsky, A.B. Searching for Safety; Transaction Publ.: Piscataway, NJ, USA, 1988.

14. Toya, H.; Skidmore, M. Economic development and the impacts of natural disasters. Econ. Lett. 2007, 94, 20-25. [CrossRef]

15. Padli, J.; Shah Habibullah, M.; Baharom, A.H. Economic impact of natural disasters' fatalities. Int. J. Soc. Econ. 2010, 37, 429-441. [CrossRef]

16. Pielke, R.A.; Agrawala, S.; Bouwer, L.M.; Burton, I.; Changnon, S.; Glantz, M.H.; Hooke, W.H.; Klein, R.J.T.; Kunkel, K.; Mileti, D.; et al. Clarifying the Attribution of Recent Disaster Losses a Response to Epstein and McCarthy. Bull. Am. Meteorol. Soc. 2005, 86, 1481-1483.

17. Kellenberg, D.K.; Mobarak, A.M. Does rising income increase or decrease damage risk from natural disasters? J. Urban Econ. 2008, 63, 788-802. [CrossRef]

18. Barredo, J.I. Normalised flood losses in Europe: 1970-2006. Nat. Hazards Earth Syst. Sci. 2009, 9, 97-104. [CrossRef]

19. Kahn, M.E. The Death Toll from Natural Disasters: The Role of Income, Geography, and Institutions. Rev. Econ. Stat. 2005, 87, 271-284. [CrossRef]

20. Crespo Cuaresma, J.; Hlouskova, J.; Obersteiner, M. Natural Disasters as Creative Destruction? Evidence from Developing Countries. Econ. Inq. 2008, 46, 214-226. [CrossRef]

21. Schumacher, I.; Strobl, E. Economic development and losses due to natural disasters: The role of hazard exposure. Ecol. Econ. 2011, 72, 97-105. [CrossRef]

22. Horwich, G. Economic Lessons of the Kobe Earthquake. Econ. Dev. Cult. Chang. 2000, 48, 521-542. [CrossRef]

23. Cavallo, E.; Galiani, S.; Noy, I.; Pantano, J. Catastrophic Natural Disasters and Economic Growth. Rev. Econ. Stat. 2013, 95, 1549-1561. [CrossRef]

24. Neumayer, E.; Plümper, T.; Barthel, F. The political economy of natural disaster damage. Glob. Environ. Chang. 2014, 24, 8-19. [CrossRef]

25. Noy, I.; Nualsri, A. Fiscal storms: public spending and revenues in the aftermath of natural disasters. Environ. Dev. Econo. 2011, 16, 113-128. [CrossRef] 
26. Kellenberg, D.; Mobarak, A.M. The Economics of Natural Disasters. Annu. Rev. Resour. Econ. 2011, 3, 297-312. [CrossRef]

27. Noy, I.; Vu, T.B. The economics of natural disasters in a developing country: The case of Vietnam. J. Asian Econ. 2010, 21, 345-354. [CrossRef]

28. Xiao, Y. LOCAL ECONOMIC IMPACTS OF NATURAL DISASTERS*. J. Reg. Sci. 2011, 51, 804-820. [CrossRef]

29. Paul, S.; Sharif, H. Analysis of Damage Caused by Hydrometeorological Disasters in Texas, 1960-2016. Geosciences 2018, 8, 384. [CrossRef]

30. Bettin, G.; Zazzaro, A. The Impact of Natural Disasters on Remittances to Low- and Middle-Income Countries. J. Dev. Stud. 2018, 54, 481-500. [CrossRef]

31. Strobl, E. The economic growth impact of natural disasters in developing countries: Evidence from hurricane strikes in the Central American and Caribbean regions. J. Dev. Econ. 2012, 97, 130-141. [CrossRef]

32. Raschky, P.A. Institutions and the losses from natural disasters. Nat. Hazards Earth Syst. Sci. 2008, 8, 627-634. [CrossRef]

33. Strömberg, D. Natural Disasters, Economic Development, and Humanitarian Aid. J. Econ. Perspect. 2007, 21, 199-222. [CrossRef]

34. Kantha, L. Time to replace the Saffir-Simpson hurricane scale? Eos Trans. AGU 2006, 87, 3-6. [CrossRef]

35. Nordhaus, W.D. The Economics of Hurricanes and Implications of Global Warming. Clim. Chang. Econ. 2010, 1, 1-20. [CrossRef]

36. Bouwer, L.M.; Botzen, W.J.W. How Sensitive are us Hurricane Damages to Climate? Comment on a Paper by W. D. Nordhaus. Clim. Chang. Econ. 2011, 2, 1-7. [CrossRef]

37. Murnane, R.J.; Elsner, J.B. Maximum wind speeds and US hurricane losses. Geophys. Res. Lett. $2012,39$. [CrossRef]

38. Alice, R.Z.; Jonathan, H.J. Dependence of US hurricane economic loss on maximum wind speed and storm size. Environ. Res. Lett. 2014, 9, 064019. [CrossRef]

39. Dorland, C.; Tol, R.S.J.; Palutikof, J.P. Vulnerability of the Netherlands and Northwest Europe to Storm Damage under Climate Change. Clim. Chang. 1999, 43, 513-535. [CrossRef]

40. Pielke, R.A., Jr.; Downton, M.W. Precipitation and Damaging Floods: Trends in the United States, $1932-97$. J. Clim. 2000, 13, 3625-3637. [CrossRef]

41. Cavallo, E.; Powell, A.; Becerra, O. Estimating the Direct Economic Damages of the Earthquake in Haiti* Econ. J. 2010, 120, F298-F312. [CrossRef]

42. Song, Y.; Park, M. A Study on Estimation Equation for Damage and Recovery Costs Considering Human Losses Focused on Natural Disasters in the Republic of Korea. Sustainability 2018, 10, 3103. [CrossRef] 